\title{
Educational level, marital status and sex as social gender discharge determinants in chronic obstructive pulmonary disease exacerbations: a time-to-event analysis
}

\author{
Orazio Valerio Giannico ${ }^{1}$, Immacolata Ambrosino² Francesco Patano$^{1}$, Cinzia Germinario¹, \\ Michele Quarto ${ }^{1}$, Anna Maria Moretti ${ }^{3}$ \\ ${ }^{1}$ Department of Biomedical Sciences and Human Oncology, University of Bari Aldo Moro; ${ }^{2}$ Local Healthcare Unit of \\ Bari, Health District 13, Bari; ${ }^{3}$ President of GISeG, Italian Group for Health and Gender, Bari, Italy
}

\begin{abstract}
The aim of this study is to evaluate, in patients hospitalized for COPD exacerbation, how educational level, marital status and sex (social gender indicators) affect the home discharge probability (main effects) and how interact with each other in affecting this probability (effect modification). Data for all patients discharged with a principal diagnosis of COPD with exacerbation (ICD-9 491.21) by Apulian hospitals between 2013 and 2017 were retrieved from the National Hospital Discharge Register Database. A multivariable multi-stratified frailty cox proportional-hazard regression with interaction terms was fitted in order to assess the effect of sex, educational level and marital status on the time-toevent for home discharge through the estimation of hazard ratios.
\end{abstract}

Correspondence: Orazio Valerio Giannico, Department of Biomedical Sciences and Human Oncology, University of Bari Aldo Moro, Piazza Giulio Cesare 11, 70124 Bari, Italy.

Mobile: +39.339 .7998312 .

E-mail: oraziovaleriogiannico@gmail.com

Key words: Chronic obstructive pulmonary disease; gender differences; educational level; marital status; female caregiver.

Contributions: OVG, study conception and design, statistical analysis, data interpretation, manuscript drafting; IA, FP, AMM, study conception and design, critical revision; $\mathrm{CG}$, data acquisition; $\mathrm{MQ}$, critical revision. All authors read and approved the final version of the manuscript.

Conflict of interest: The authors declare no conflict of interest.

Acknowledgments: The authors would like to thank the Epidemiologic Observatory of Apulia Region for data supply.

Received for publication: 17 December 2018.

Accepted for publication: 14 May 2019.

(C) Copyright O.V. Giannico et al., 2019

Licensee PAGEPress, Italy

Monaldi Archives for Chest Disease 2019; 89:1017

doi: 10.4081/monaldi.2019.1017

This article is distributed under the terms of the Creative Commons Attribution Noncommercial License (by-nc 4.0) which permits any noncommercial use, distribution, and reproduction in any medium, provided the original author(s) and source are credited.
Adjusting for several patient and hospitalization characteristics and for healthcare facilities, low educational level $(<8$ years of schooling) is associated with a lower probability of being discharged to home in both sexes and in all marital status categories (HR 0.92, 95\%CI 0.87-0.97, $\mathrm{p}=0.0020$ ). Female sex is associated with a lower probability of being discharged to home only in married patients (HR 0.83, 95\%CI 0.78-0.88, $\mathrm{p}<0.0001$ ). Marital status different from married is associated with a lower probability of being discharged to home only in male patients, in particular single patients (HR 0.82, 95\%CI 0.74-0.92, $\mathrm{p}=0.0009$ ), separated or divorced patients (HR 0.71, 95\% CI 0.58-0.86, $\mathrm{p}=0.0005$ ) and widowed patients (HR $0.87,95 \%$ CI $0.80-0.95, \mathrm{p}=0.0018$ ). Differently from findings about protective effect of education, the evidence of different effects of sex on home discharge probability among civil statuses and of different effect of civil status among sexes is supposed to be a proxy for social gender health and healthcare inequalities.

\section{Introduction}

Even though chronic obstructive pulmonary disease (COPD) was historically considered a disease that mainly affected man, in the last years there has been a rapid increase of prevalence, morbidity, mortality and hospitalization COPD-related in women all over the world [1-6]. It is now well known that female sex affect COPD with regard to risk factors, epidemiology, diagnosis, comorbidities, treatment and outcomes, determining severe exacerbations, higher number of hospitalizations and prolonged length of stay [2-5,7-10].

Along with sex, another factor that seems to affect COPD prevalence and prognosis is educational level, an indicator of socioeconomic status [11-18], in line with a recent meta-analysis on general population that identified the socioeconomic status as a sure determinant of premature mortality in men and women [19].

Findings from a Norwegian study in 1995 have shown that educational level is a risk factor for airway disorders independent of smoking and occupational airborne exposure [11], while a Danish study in 2003 has reported that low education was strongly associated with respiratory mortality in both sexes comparing the highest level of education ( $\geq 8$ years) with the lowest ( $<8$ years); despite smoking rates were inversely associated with educational level, the social gradient was not modified by adjustment for smoking [12]. According to a Chinese study in 2011, compared to subjects with high educational level ( $\geq 12$ years), subjects with low educational 
level ( $<9$ years) had a significantly increased risk of COPD after adjusting for age, sex, smoking status, passive smoking and geographic regions [13]. A European study in 2007 has demonstrated that lower educational level was associated with increased risk of prevalent and incident chronic bronchitis and asthma with no atopy [14]. A systematic review in 2012 has found, with few exceptions, significant inverse associations between socioeconomic status (mainly determined by the level of education) and COPD prevalence, incidence, mortality and hospitalization that were consistent across gender, age, and population [15]. According to an American study in 2012, poorer health literacy was associated with worse COPD severity, greater COPD helplessness, worse respiratory-specific health-related quality of life, higher likelihood of COPD-related hospitalizations and COPD-related emergency department visits [16]. Findings from a Danish study in 2014 has reported that, adjusting for sex, age, FEV1\%pred, dyspnea, frequency of previous exacerbations and smoking, shortest school education ( $<8$ years), was associated with a higher risk of COPD exacerbations and higher risk of all-cause mortality [17]. Findings from an American study in 2009 have shown higher mortality rates of patients with low educational level (none/primary/secondary school) even after adjusting for smoking habits [18].

Related to the previous two indicators as social determinant of health is marital status: as far as marriage is concerned, very few studies have investigated its relationship with COPD [18,20-21] or the social, psychological and economic burden of COPD in consort caregivers [22-23]. The aforementioned American study of 2009, which analyzed also the impact of remarriage on health outcome based on a large-scale population survey, have shown that remarriage significantly correlates with reduced risk of COPD incidence, even after adjusting for smoking habits [18]. In 2012, a study on nutritional status among patients with COPD has shown that patients who lived alone had worse nutritional status than those who did not live alone, and female participants had worse nutritional status than their male counterparts [20]. On the contrary, a Korean study in 2015 among never-smoker patients could not demonstrate a relationship between living alone and COPD development [21]. According to two surveys in 2007 and in 2015 about the burden of caregiving for patients with COPD, the disease is supposed to determine a significant impact on the quality of life of caregivers, that are mainly female and married $[22,23]$.

The aim of this study is to evaluate, in patients hospitalized for COPD exacerbation, how educational level, marital status and sex (social gender indicators) affect the home discharge probability (main effects) and how interact with each other in affecting this probability (effect modification).

\section{Patients and Methods}

\section{Study design and participants}

This is a retrospective cohort study. Data for all patients discharged with a principal diagnosis of obstructive chronic bronchitis with exacerbation (ICD-9 491.21) by Apulian hospitals between January 1, 2013 and December 31, 2017 were retrieved from the National Hospital Discharge Register Database. We did not use data collected earlier than 2013 because prior to that period there were not yet in the database information about marital status and educational level. Patients were excluded if younger than 40 or older than 99 years.

\section{Procedures}

Together with sex, we used educational level and marital status as social gender indicators. According to literature $[12,17]$, subjects with education $<8$ years, $\geq 8$ years and unknown were classified respectively as low, middle/high and not defined educational level. Marital status was defined by five categories: married, single, separated/divorced, widowed and not defined. Patients were divided for age in ten-years classes from 40 to 99 years. Relying on National Classification of Italian Areas for peripherality level [24], we divided patients as residents in central area, peripheral area and extra-regional area if they lived $<20^{\prime}$ from nearest urban pole, $>20$ ' from nearest urban pole [24] or not in Apulia, respectively (Travel times are calculated as a mean for the municipality of residence). Cold season hospitalization was defined by a date of hospital admission between November and February, according to literature [25]. If the considered hospitalization was not the first for the patients, it was classified as repeated hospitalization. Respiratory therapy was identified by the ICD-9 code 93.9. Presence of comorbidities indicates at least one disease code in the secondary diagnosis fields. Healthcare facilities were identified by their unique codes and different structures of same institutions were grouped together, for a total of 53 macro-hospitals.

\section{Outcomes}

Discharge types were defined by these five categories: to home (discharge codes 2, 4 and 9), voluntary (5), to another hospitalization scheme or activity (7), to another facility (3,6 and 8) and death (1). We use as good clinical outcome home discharge.

\section{Statistical analysis}

Statistical analysis was performed using R 3.5.1 (released on 2018-07-02). Categorical variables were reported as absolute and relative frequencies and compared through Pearson $\chi^{2}$ test. Continuous variables were reported as median and IQR and compared through Wilcoxon and Kruskal Wallis rank sum test, in order to deal with non-normality, evaluated through Kolmogorov-Smirnov test, and heteroscedasticity, evaluated through Bartlett test.

A multivariable multi-stratified frailty cox proportional-hazard regression was then fitted in order to assess the effect of sex, educational level and marital status on the time-to-event for home discharge through the estimation of adjusted hazard ratios. The timeto-event was the length of hospital stay in days. Efron computation algorithm was used to handle tied event times. In order to study effect modification between discharge determinants, we fitted different models with the interaction terms originated from the combination of the three social gender indicators. Not-significant interaction terms were removed from the model. For significant interactions, we reported hazard ratios for the various combinations of factors and ratio of hazard ratios as a measure of effect modification. The proportional hazard assumption was verified through the Grambsch-Therneau score test as well as through the visual inspection of the scatterplot of Schoenfeld residuals versus time. Variables of adjustment are included as strata if they were statistically significant at Wald test but they not respected proportional hazard assumption, or if they were supposed to be clinically relevant. The strata are age (ten-year age groups), calendar year of discharge, admission in cold season, residence with respect to urban poles, repeated hospitalization, respiratory therapy and presence of comorbidities. The goodness of fit of the model was assessed through the Grønnesby-Borgan deciles test. In order to provide an adjustment for different healthcare facilities, we included in the model a gamma-distributed frailty with four degrees of freedom 
estimated through a penalized fitting procedure. Statistical significance $\alpha$ was fixed to 0.05 .

\section{Results}

In retrospective study, 12,136 patients aged between 40 and 99 years were discharged from Apulian hospitals with a principal diagnosis of COPD with acute exacerbation during the inclusion period.

Table 1 shows patient and hospitalization characteristics. The majority of patients were males $(7635 ; 62.9 \%)$, married $(6905$; $56.9 \%)$, with low educational level $(9737 ; 80.2 \%)$ and discharged to home $(11,140 ; 91.8 \%)$. Only 111 patients $(0.9 \%)$ died during the hospitalization. Median length of hospital stay was 8 days

Tables 2, 3 and 4 show distribution of patient and hospitalization characteristics by sex, educational level and marital status, respectively. Except for residence by sex $(\mathrm{p}=0.82)$ and admission in cold season by marital status $(\mathrm{p}=0.11)$, all variables showed different distribution among groups at univariable analysis $(\mathrm{p}<0.05)$. Length of hospital stay shows different rank distribution among different sex $(p<0.0001)$, educational level $(p<0.0001)$ and marital status $(\mathrm{p}<0.0001)$.

Results of multivariable multi-stratified frailty cox regression for home discharge are shown in Table 5. Hazard ratios are mutually adjusted and adjusted for age, year of discharge, admission in cold season, residence, repeated hospitalization, respiratory therapy, presence of comorbidities and healthcare facility. A hazard ratio $<1$ indicates a lower probability of being discharged to home compared with the reference category. Data shows that low educational level is associated with a lower probability of being discharged to home (HR 0.92, 95\% CI 0.87-0.97, p=0.0020) in both sex and in all marital status categories (Interaction terms with educational level were removed from the model because not significant; $p>0.05$ ). On the contrary, sex and marital status seem to interacts with each other in affecting this probability. In particular, in male patients and considering married ones as reference category, are less likely to be discharged to home single patients (HR $0.82,95 \%$ CI $0.74-$ $0.92, \mathrm{p}=0.0009$ ), separated or divorced patients (HR $0.71,95 \% \mathrm{CI}$ $0.58-0.86, \mathrm{p}=0.0005$ ) and widowed patients (HR $0.87,95 \% \mathrm{CI}$ $0.80-0.95, \mathrm{p}=0.0018$ ), while patients with marital status not defined are not significantly different from married ones $(p=0.065)$, suggesting that these patients are mainly married. When we considered female patients, instead, we could not demonstrate any significant difference in the probability of being discharged to home between patients married and single $(p=0.37)$, separate or divorced $(p=0.28)$ and widowed $(p=0.56)$. Also in this case, there is not any difference between married patients and those with marital status not known $(\mathrm{p}=0.56)$. So female sex seems to modify the effect of a marital status different from married or not defined on home discharge probability, in particular with regard to single (HRR 1.29, 95\%CI 1.08-1.54, $\mathrm{p}=0.0050$ ), separated or divorced (HRR 1.64, 95\%CI 1.18-2.29, p=0.0036) and widowed (HRR $1.12,95 \%$ CI $1.00-1.26, \mathrm{p}=0.049)$. When we analyze the effect of sex on home discharge, females sex is associated with a lower probability of being discharged to home only in married patients (HR $0.83,95 \%$ CI $0.78-0.88, \mathrm{p}<0.0001$ ) and in patients with not defined marital status, that are probably married (HR $0.80,95 \% \mathrm{CI}$ $0.73-0.88, \mathrm{p}<0.0001)$, while seems not to affect home discharge probability in patients single $(\mathrm{p}=0.42)$, separated or divorced $(p=0.064)$ and widowed $(p=0.18)$. So marital status different from married or not defined seems to modify the effect of female sex on home discharge probability, in particular single (HRR 1.29, 95\% CI
$1.08-1.54, \mathrm{p}=0.0050)$, separated or divorced (HRR 1.64, 95\%CI $1.18-2.29, \mathrm{p}=0.0036)$ and widowed (HRR 1.12, 95\%CI 1.00-1.26, $\mathrm{p}=0.049)$.

\section{Discussion}

Regarding the level of education, findings from our study have shown that low literacy is associated with lower probability of being discharged to home in patients hospitalized for COPD with acute exacerbation, in agreement with those from similar studies and systematic reviews [11-12,15-19]. Our findings are partially

Table 1. Characteristics of patients discharged with a principal diagnosis of COPD with exacerbation (ICD9 491.21). Data are $n$ (\%) or median (IQR).

Total $(n=12,136)$

\begin{tabular}{|c|c|}
\hline $\begin{array}{l}\text { Educational level } \\
\text { Middle/high }(\geq 8 \text { years }) \\
\text { Low }(<8 \text { years }) \\
\text { Not defined }\end{array}$ & $\begin{array}{c}2192(18.1) \\
9737(80.2) \\
207(1.7)\end{array}$ \\
\hline $\begin{array}{l}\text { Marital status } \\
\text { Married } \\
\text { Single } \\
\text { Separated/divorced } \\
\text { Widowed } \\
\text { Not defined }\end{array}$ & $\begin{array}{l}6905(56.9) \\
746(6.1) \\
216(1.8) \\
2076(17.1) \\
2193(18.1)\end{array}$ \\
\hline $\begin{array}{l}\text { Sex } \\
\text { Male } \\
\text { Female }\end{array}$ & $\begin{array}{l}7635(62.9) \\
4501(37.1)\end{array}$ \\
\hline $\begin{array}{l}\text { Age (years) } \\
40-49 \\
50-59 \\
60-69 \\
70-79 \\
80-89 \\
90-99\end{array}$ & $\begin{array}{l}206(1.7) \\
701(5.8) \\
1885(15.5) \\
3977(32.8) \\
4494(37.0) \\
873(7.2)\end{array}$ \\
\hline $\begin{array}{l}\text { Year of discharge } \\
2013 \\
2014 \\
2015 \\
2016 \\
2017\end{array}$ & $\begin{array}{l}3456(28.5) \\
3105(25.6) \\
2309(19.0) \\
1725(14.2) \\
1541(12.7)\end{array}$ \\
\hline $\begin{array}{l}\text { Residence } \\
\text { Central area } \\
\text { Peripheral area } \\
\text { Extra-regional area }\end{array}$ & $\begin{array}{c}7948(65.5) \\
4160(34.3) \\
28(0.2)\end{array}$ \\
\hline Admission during cold season & $4828(39.8)$ \\
\hline Repeated hospitalization & $2632(21,7)$ \\
\hline Respiratory therapy & $816(6.7)$ \\
\hline Presence of comorbidities & $11,467(94.5)$ \\
\hline $\begin{array}{l}\text { Discharge type } \\
\text { Home } \\
\text { Voluntary } \\
\text { Another hospitalization } \\
\text { Another facility } \\
\text { Death }\end{array}$ & $\begin{array}{c}11,140(91.8) \\
446(3.7) \\
337(2.8) \\
102(0.8) \\
111(0.9)\end{array}$ \\
\hline Length of hospital stay (days) & $8.0(7.0)$ \\
\hline
\end{tabular}


consistent with previous studies regarding relationship of COPDrelated outcomes with sex [2-5,7-10] and marital status [18,20], but to completion of and in addition to these relevant results, at medical, epidemiological and socio-economic level the major strengths of this analysis lies in the evidence of different effects of sex among civil statuses and of different effect of civil status among sexes. Female sex not only is associated with a lower probability of being discharged to home only in married patients, but nullifies the protective effects that marriage shows in male patients. On the other hand, marital status different from married not only is associated with a lower probability of being discharged to home only in male patients, but nullifies the protective effects that male sex shows in married patients. In summary, according to our findings the only combination of sex and marital status that is supposed to be protective in terms of home discharge probability is male and married, determining the all other combination a longer time to home return. We believe these findings to be of interest for several reasons. First of all, the shorter time to home discharge only in male and married patients has confirmed the predominant role of women as principal caregivers in the familiar context [22-23]. This accounts for increased significant disease burden in male unmarried patients and in all female patients derived from social gender inequalities. For women hospitalized, has not emerged any difference in outcome between married and not married patients, suggesting for husbands a minor role in home care of patients with COPD. Moreover, the mutual effect modification between sex and marital status seemed to confirm that sex differences in COPD yet reported in literature [2-5,7-10] could be partially explained by social determinants in addition to physiopathological, anatomical and biological causes. Finally, differences in home discharge probability determined by these gender inequalities also account for a significant economic burden which has his roots in costs mainly related to longer length of hospital stay. Instead, the lack of significant effect modification of sex or marital status upon educational level is supposed to be a highly positive signal in terms of gender equality and literacy.

Table 2. Characteristics of patients discharged with a principal diagnosis of COPD with exacerbation (ICD9 491.21) by sex. Data are $n$ $(\%)$ or median (IQR), p-values are from Pearson's $\chi^{2}$ test or Wilcoxon rank sum test.

\begin{tabular}{|c|c|c|c|}
\hline Sex & Males $(\mathrm{n}=7635)$ & Females $(n=4501)$ & p-value \\
\hline $\begin{array}{l}\text { Educational level } \\
\text { Middle/high ( } \geq 8 \text { years) } \\
\text { Low (<8 years) } \\
\text { Not defined }\end{array}$ & $\begin{array}{c}1474(19.3) \\
6032(79.0) \\
129(1.7)\end{array}$ & $\begin{array}{r}718(16.0) \\
3705(82.3) \\
78(1.7)\end{array}$ & $<0.0001$ \\
\hline $\begin{array}{l}\text { Marital status } \\
\text { Married } \\
\text { Single } \\
\text { Separated/divorced } \\
\text { Widowed } \\
\text { Not defined } \\
\end{array}$ & $\begin{array}{c}4950(64.8) \\
442(5.8) \\
149(2.0) \\
789(10.3) \\
1305(17.1)\end{array}$ & $\begin{array}{r}1955(43.4) \\
304(6.8) \\
67(1.5) \\
1287(28.6) \\
888(19.7)\end{array}$ & $<0.0001$ \\
\hline $\begin{array}{l}\text { Age (years) } \\
40-49 \\
50-59 \\
60-69 \\
70-79 \\
80-89 \\
90-99\end{array}$ & $\begin{array}{c}129(1.7) \\
441(5.8) \\
1323(17.3) \\
2699(35.3) \\
2662(34.9) \\
381(5.0)\end{array}$ & $\begin{array}{r}77(1.7) \\
260(5.8) \\
562(12.5) \\
1278(28.4) \\
1832(40.7) \\
492(10.9)\end{array}$ & $<0.0001$ \\
\hline $\begin{array}{l}\text { Year of discharge } \\
2013 \\
2014 \\
2015 \\
2016 \\
2017 \\
\end{array}$ & $\begin{array}{r}2188(28.7) \\
1988(26.0) \\
1444(18.9) \\
1029(13.5) \\
986(12.9)\end{array}$ & $\begin{array}{r}1268(28.2) \\
1117(24.8) \\
865(19.2) \\
696(15.5) \\
555(12.3)\end{array}$ & 0.031 \\
\hline $\begin{array}{l}\text { Residence } \\
\text { Central area } \\
\text { Peripheral area } \\
\text { Extra-regional area }\end{array}$ & $\begin{array}{c}5007(65.6) \\
2609(34.2) \\
19(0.2)\end{array}$ & $\begin{array}{c}2941(65.3) \\
1551(34.5) \\
9(0.2)\end{array}$ & 0.82 \\
\hline Admission during cold season & $2979(39.0)$ & $1849(41.1)$ & 0.025 \\
\hline Repeated hospitalization & $1930(25.3)$ & $702(15.6)$ & $<0.0001$ \\
\hline Respiratory therapy & $553(7.2)$ & $263(5.8)$ & 0.0029 \\
\hline Presence of comorbidities & $7177(94.0)$ & $4290(95.3)$ & 0.0022 \\
\hline $\begin{array}{l}\text { Discharge type } \\
\text { Home } \\
\text { Voluntary } \\
\text { Another hospitalization } \\
\text { Another facility } \\
\text { Death }\end{array}$ & $\begin{array}{c}6962(91.2) \\
301(3.9) \\
246(3.2) \\
59(0.8) \\
67(0.9)\end{array}$ & $\begin{array}{c}4178(92.8) \\
145(3.2) \\
91(2.0) \\
43(1.0) \\
44(1.0)\end{array}$ & 0.0003 \\
\hline Length of hospital stay (days) & $8.0(6.0)$ & $8.0(6.0)$ & $<0.0001$ \\
\hline
\end{tabular}


As far as methodological aspects are concerned, the second strength of this study lies at four different level: reliability and accessibility of the great amount of data retrieved from national discharge databases, choose of home discharge as a positive hospitalization outcome, adjustment for several potential confounding factors and use of a stratified cox regression analysis with frailty term for these particular kinds of data and outcomes.

The main limitation of our analysis was the absence of any adjustments for smoking habits of patients, determined by the lack in our data of reliable information about tobacco smoking, a limit intrinsic to the type of data source. This is not a big concern to our opinion, because some previous studies have proved that association between COPD outcomes and sex, educational level and marital status is constant even after smoking habits adjustment $[8,11$ $13,15,17-18]$, but further studies with adjustment for smoking status are needed to confirm these results. Another limit is the restriction of this first analysis only to a single specific ICD 9 code (491.21 - obstructive chronic bronchitis with acute exacerbation), excluding other COPD-related codes (491.xx - chronic bronchitis, 492.xx - emphysema; 493.2 - chronic obstructive asthma; 496.xx chronic airway obstruction not classified), a methodological choice dictated by the desire to make the sample as homogeneous as possible while avoiding as far as possible any bias related to the great variability in discharge codes compilation among physicians. Further studies are needed in order to extend these results to patients discharged with other diagnostic codes.

In conclusion, consistent findings were noted for all the social gender indicators analyzed and for some of their interactions. We are not aware of any published study investigating these indicators and their interactions in patients with COPD, particularly in those hospitalized for acute exacerbation of the disease e with this statistical approach. Differently from the findings about protective effect of education, the evidence of different effects of sex on home discharge probability among civil statuses and of different effect of civil status among sexes is supposed to be a proxy for social gender health and healthcare inequalities.

Table 3. Characteristics of patients discharged with a principal diagnosis of COPD with exacerbation (ICD9 491.21) by educational level. Data are n $(\%)$ or median (IQR), p-values are from Pearson's $\chi^{2}$ test or Kruskal-Wallis rank sum test.

\begin{tabular}{|c|c|c|c|c|}
\hline Educational level & Middle/high ( $\mathrm{n}=2192)$ & Low $(n=9737)$ & Not defined ( $n=207)$ & p-value \\
\hline $\begin{array}{l}\text { Marital status } \\
\text { Married } \\
\text { Single } \\
\text { Separated/divorced } \\
\text { Widowed } \\
\text { Not defined }\end{array}$ & $\begin{array}{c}1474(67.2) \\
157(7.2) \\
64(2.9) \\
189(8.6) \\
308(14.1)\end{array}$ & $\begin{array}{c}5344(54.9) \\
582(6.0) \\
149(1.5) \\
1856(19.1) \\
1806(18.5)\end{array}$ & $\begin{array}{c}87(42.0) \\
7(3.4) \\
3(1.4) \\
31(15.0) \\
79(38.2)\end{array}$ & $<0.0001$ \\
\hline $\begin{array}{l}\text { Sex } \\
\text { Male } \\
\text { Female }\end{array}$ & $\begin{array}{r}1474(67.2) \\
718(32.8)\end{array}$ & $\begin{array}{l}6032(61.9) \\
3705(38.1)\end{array}$ & $\begin{array}{r}129(62.3) \\
78(37.7)\end{array}$ & $<0.0001$ \\
\hline $\begin{array}{l}\text { Age (years) } \\
40-49 \\
50-59 \\
60-69 \\
70-79 \\
80-89 \\
90-99\end{array}$ & $\begin{array}{c}126(5.7) \\
348(15.9) \\
613(28.0) \\
619(28.2) \\
406(18.5) \\
80(3.6)\end{array}$ & $\begin{array}{c}78(0.8) \\
340(3.5) \\
1248(12.8) \\
3289(33.8) \\
4006(41.1) \\
776(8.0)\end{array}$ & $\begin{array}{l}2(1.0) \\
13(6.3) \\
24(11.6) \\
69(33.3) \\
82(39.6) \\
17(8.2)\end{array}$ & $<0.0001$ \\
\hline $\begin{array}{l}\text { Year of discharge } \\
2013 \\
2014 \\
2015 \\
2016 \\
2017 \\
\end{array}$ & $\begin{array}{l}586(26.7) \\
515(23.5) \\
431(19.7) \\
322(14.7) \\
338(15.4)\end{array}$ & $\begin{array}{r}2870(29.5) \\
2590(26.6) \\
1878(19.3) \\
1403(14.4) \\
996(10.2)\end{array}$ & $\begin{array}{c}0(0.0) \\
0(0.0) \\
0(0.0) \\
0(0.0) \\
207(100.0)\end{array}$ & $<0.0001$ \\
\hline $\begin{array}{l}\text { Residence } \\
\text { Central area } \\
\text { Peripheral area } \\
\text { Extra-regional area }\end{array}$ & $\begin{array}{c}1525(69.6) \\
660(30.1) \\
7(0.3)\end{array}$ & $\begin{array}{c}6316(64.9) \\
3409(35.0) \\
12(0.1)\end{array}$ & $\begin{array}{c}107(51.7) \\
91(44.0) \\
9(4.3)\end{array}$ & $<0.0001$ \\
\hline Admission during cold season & $926(42.2)$ & 3825 (39.3) & $77(37.2)$ & 0.028 \\
\hline Repeated hospitalization & $390(17.8)$ & $2201(22.6)$ & $41(19.8)$ & $<0.0001$ \\
\hline Respiratory therapy & $147(6.7)$ & $665(6.8)$ & $4(1.9)$ & 0.021 \\
\hline Presence of comorbidities & $2020(92.2)$ & $9242(94.9)$ & $205(99.0)$ & $<0.0001$ \\
\hline $\begin{array}{l}\text { Discharge type } \\
\text { Home } \\
\text { Voluntary } \\
\text { Another hospitalization } \\
\text { Another facility } \\
\text { Death }\end{array}$ & $\begin{array}{c}2032(92.7) \\
95(4.3) \\
31(1.4) \\
18(0.8) \\
16(0.7)\end{array}$ & $\begin{array}{c}8921(91.6) \\
341(3.5) \\
302(3.1) \\
83(0.9) \\
90(0.9)\end{array}$ & $\begin{array}{c}187(90.3) \\
10(4.8) \\
4(1.9) \\
1(0.5) \\
5(2.4)\end{array}$ & 0.0003 \\
\hline Length of hospital stay (days) & $7.0(5.0)$ & $8.0(6.0)$ & $8.0(6.0)$ & $<0.0001$ \\
\hline
\end{tabular}


Table 4. Characteristics of patients discharged with a principal diagnosis of COPD with exacerbation (ICD9 491.21) by marital status. Data are n (\%) or median (IQR), p values are from Pearson's $\chi^{2}$ test or Kruskal-Wallis rank sum test.

\begin{tabular}{|c|c|c|c|c|c|c|}
\hline Marital status & $\begin{array}{l}\text { Married } \\
(\mathrm{n}=6905)\end{array}$ & $\begin{array}{c}\text { Single } \\
(n=746)\end{array}$ & $\begin{array}{l}\text { Separated/divorced } \\
(\mathrm{n}=216)\end{array}$ & $\begin{array}{l}\text { Widowed } \\
(n=2076)\end{array}$ & $\begin{array}{l}\text { Not defined } \\
(n=2193)\end{array}$ & p-value \\
\hline $\begin{array}{l}\text { Educational level } \\
\text { Middle/high ( } \geq 8 \text { years) } \\
\text { Low (<8 years) } \\
\text { Not defined }\end{array}$ & $\begin{array}{c}1474(21.3) \\
5344(77.4) \\
87(1.3)\end{array}$ & $\begin{array}{c}157(21.0) \\
582(78.0) \\
7(0.9)\end{array}$ & $\begin{array}{r}64(29.6) \\
149(69.0) \\
3(1.4)\end{array}$ & $\begin{array}{c}189(9.1) \\
1856(89.4) \\
31(1.5)\end{array}$ & $\begin{array}{r}308(14.0) \\
1806(82.4) \\
79(3.6)\end{array}$ & $<0.0001$ \\
\hline $\begin{array}{l}\text { Sex } \\
\text { Male } \\
\text { Female }\end{array}$ & $\begin{array}{l}4950(71.7) \\
1955(28.3)\end{array}$ & $\begin{array}{l}442(59.2) \\
304(40.8)\end{array}$ & $\begin{array}{r}149(69.0) \\
67(31.0)\end{array}$ & $\begin{array}{r}789(38.0) \\
1287(62.0) \\
\end{array}$ & $\begin{array}{r}1305(59.5) \\
888(40.5)\end{array}$ & $<0.0001$ \\
\hline $\begin{array}{l}\text { Age (years) } \\
40-49 \\
50-59 \\
60-69 \\
70-79 \\
80-89 \\
90-99\end{array}$ & $\begin{array}{c}114(1.7) \\
440(6.4) \\
1320(19.1) \\
2531(36.7) \\
2245(32.5) \\
255(3.7)\end{array}$ & $\begin{array}{c}53(7.1) \\
97(13.0) \\
107(14.3) \\
212(28.4) \\
213(28.6) \\
64(8.6)\end{array}$ & $\begin{array}{l}11(5.1) \\
42(19.4) \\
63(29.2) \\
70(32.4) \\
30(13.9) \\
0(0.0)\end{array}$ & $\begin{array}{c}4(0.2) \\
15(0.7) \\
100(4.8) \\
505(24.3) \\
1083(52.2) \\
369(17.8)\end{array}$ & $\begin{array}{c}24(1.1) \\
107(4.9) \\
295(13.4) \\
659(30.1) \\
923(42.1) \\
185(8.4)\end{array}$ & $<0.0001$ \\
\hline $\begin{array}{l}\text { Year of discharge } \\
2013 \\
2014 \\
2015 \\
2016 \\
2017\end{array}$ & $\begin{array}{r}1974(28.6) \\
1747(25.3) \\
1323(19.2) \\
995(14.4) \\
866(12.5)\end{array}$ & $\begin{array}{l}199(26.7) \\
181(24.3) \\
146(19.6) \\
107(14.3) \\
113(15.1)\end{array}$ & $\begin{array}{l}52(24.1) \\
37(17.1) \\
55(25.5) \\
34(15.7) \\
38(17.6)\end{array}$ & $\begin{array}{l}529(25.5) \\
502(24.2) \\
360(17.3) \\
380(18.3) \\
305(14.7)\end{array}$ & $\begin{array}{l}702(32.0) \\
638(29.1) \\
425(19.4) \\
209(9.5) \\
219(10.0)\end{array}$ & $<0.0001$ \\
\hline $\begin{array}{l}\text { Residence } \\
\text { Central area } \\
\text { Peripheral area } \\
\text { Extra-regional area }\end{array}$ & $\begin{array}{c}4559(66.0) \\
2331(33.8) \\
15(0.2)\end{array}$ & $\begin{array}{c}544(72.9) \\
195(26.1) \\
7(0.9)\end{array}$ & $\begin{aligned} 158 & (73.1) \\
57 & (26.4) \\
1 & (0.5)\end{aligned}$ & $\begin{array}{c}1324(63.8) \\
749(36.1) \\
3(0.1)\end{array}$ & $\begin{array}{c}1363(62.1) \\
828(37.8) \\
2(0.1)\end{array}$ & $<0.0001$ \\
\hline Admission during cold season & $2771(40.1)$ & $314(42.1)$ & $70(32.4)$ & $810(39.0)$ & $863(39.4)$ & 0.11 \\
\hline Repeated hospitalization & 1497 (21.7) & $172(23.1)$ & $70(32.4)$ & 472 (22.7) & $421(19.2)$ & 0.0001 \\
\hline Respiratory therapy & $410(5.9)$ & $41(5.5)$ & $13(6.0)$ & $136(6.6)$ & $216(9.8)$ & $<0.0001$ \\
\hline Presence of comorbidities & $6493(94.0)$ & $704(94.4)$ & $200(92.6)$ & $1964(94.6)$ & $2106(96.0)$ & 0.0062 \\
\hline $\begin{array}{l}\text { Discharge type } \\
\text { Home } \\
\text { Voluntary } \\
\text { Another hospitalization } \\
\text { Another facility } \\
\text { Death } \\
\end{array}$ & $\begin{array}{c}6361(92.1) \\
263(3.8) \\
183(2.7) \\
50(0.7) \\
48(0.7) \\
\end{array}$ & $\begin{array}{c}676(90.6) \\
28(3.7) \\
20(2.7) \\
14(1.9) \\
8(1.1)\end{array}$ & $\begin{array}{c}194(89.8) \\
7(3.2) \\
13(6.0) \\
0(0.0) \\
2(0.9)\end{array}$ & $\begin{array}{c}1888(90.9) \\
55(2.6) \\
77(3.7) \\
23(1.1) \\
33(1.6) \\
\end{array}$ & $\begin{array}{c}2021(92.2) \\
93(4.2) \\
44(2.0) \\
15(0.7) \\
20(0.9) \\
\end{array}$ & $<0.0001$ \\
\hline Length of hospital stay (days) & $8.0(6.0)$ & $8.0(7.0)$ & $8.0(7.0)$ & $9.0(6.0)$ & $8.0(6.0)$ & $<0.0001$ \\
\hline
\end{tabular}

Table 5. Hazard ratios for home discharge. Mutually adjusted and adjusted for age, calendar year of discharge, residence, admission in cold season, repeated hospitalization, respiratory therapy, presence of comorbidities and health-care facility.

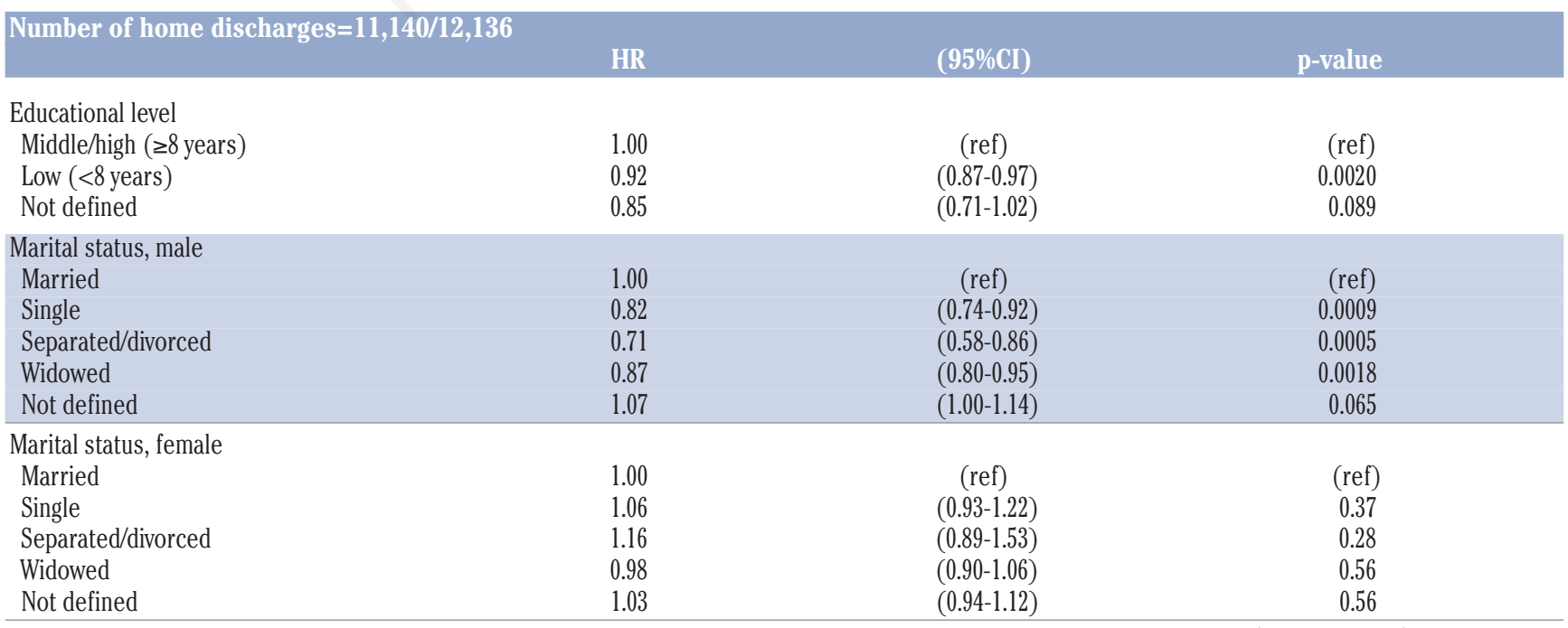

To be continued on next page 
Table 5. Continued from previous page.

\begin{tabular}{|c|c|c|c|}
\hline Number of home discharges=11,140/12,136 & HR & $(95 \% \mathrm{CI})$ & p-value \\
\hline $\begin{array}{l}\text { Sex, married } \\
\text { Male } \\
\text { Female }\end{array}$ & $\begin{array}{l}1.00 \\
0.83\end{array}$ & $\begin{array}{c}\text { (ref) } \\
(0.78-0.88)\end{array}$ & $\begin{array}{r}\text { (ref) } \\
<0.0001\end{array}$ \\
\hline $\begin{array}{l}\text { Sex, single } \\
\text { Male } \\
\text { Female }\end{array}$ & $\begin{array}{l}1.00 \\
1.07\end{array}$ & $\begin{array}{c}\text { (ref) } \\
(0.91-1.27)\end{array}$ & $\begin{array}{l}\text { (ref) } \\
0.42\end{array}$ \\
\hline $\begin{array}{l}\text { Sex, separated/divorced } \\
\text { Male } \\
\text { Female }\end{array}$ & $\begin{array}{l}1.00 \\
1.36 \\
\end{array}$ & $\begin{array}{c}\text { (ref) } \\
(0.98-1.89)\end{array}$ & $\begin{array}{l}\text { (ref) } \\
0.064\end{array}$ \\
\hline $\begin{array}{l}\text { Sex, widowed } \\
\text { Male } \\
\text { Female }\end{array}$ & $\begin{array}{l}1.00 \\
0.93\end{array}$ & $\begin{array}{c}(\text { ref }) \\
(0.84-1.03)\end{array}$ & $\begin{array}{r}\text { (ref) } \\
0.18\end{array}$ \\
\hline $\begin{array}{l}\text { Sex, MSND } \\
\text { Male } \\
\text { Female }\end{array}$ & $\begin{array}{l}1.00 \\
0.80\end{array}$ & $\begin{array}{c}\text { (ref) } \\
(0.73-0.88)\end{array}$ & $\begin{array}{r}\text { (ref) } \\
<0.0001\end{array}$ \\
\hline & HRR & $(95 \% \mathrm{CI})$ & p-value \\
\hline $\begin{array}{l}\text { Marital status and sex } \\
\text { ₹ Single/separated/divorced/widowed/MSND: female } \\
\text { Single: female } \\
\text { Separated/divorced: female } \\
\text { Widowed: female } \\
\text { MSND: female }\end{array}$ & $\begin{array}{l}1.00 \\
1.29 \\
1.64 \\
1.12 \\
0.96\end{array}$ & $\begin{array}{c}\text { (ref) } \\
(1.08-1.54) \\
(1.18-2.29) \\
(1.00-1.26) \\
(0.86-1.07)\end{array}$ & $\begin{array}{r}\text { (ref) } \\
0.0050 \\
0.0036 \\
0.049 \\
0.49\end{array}$ \\
\hline
\end{tabular}

HR, hazard ratio; HRR, ratio of hazard ratios; MSND, marital status not defined.

\section{References}

1. Mannino D, Homa D, Akimbami L, et al. Chronic obstructive pulmonary disease surveillance: United States, 1971-2000. MMWR Surveill Summ 2002;51:1-16.

2. Aryal S, Diaz-Guzman E, Mannino DM. Influence of sex on chronic obstructive pulmonary disease risk and treatment outcomes. Int J Chron Obstruct Pulmon Dis 2014;9:1145-54.

3. Barnes PJ. Sex differences in chronic obstructive pulmonary disease mechanisms. Am J Respir Crit Care Med 2016;193: 813-24.

4. Cote CG, Chapman KR. Diagnosis and treatment considerations for women with COPD. Int J Clin Pract 2009;63:486-93.

5. Han MK, Postma D, Mannino DM, et al. Gender and chronic obstructive pulmonary disease. Why it matters. Am J Respir Crit Care Med 2007;176:1179-84.

6. Soriano JB, Maier WC, Egger P, et al. Recent trends in physician diagnosed COPD in women and men in the UK. Thorax 2000;55:789-94.

7. Camp PG, O’Donnell DE, Postma DS. Chronic obstructive pulmonary disease in men and women. Myths and reality. Proc Am Thorac Soc 2009;6:535-8.

8. Celli B, Vestbo J, Jenkins CR, et al. Sex differences in mortality and clinical expressions of patients with chronic obstructive pulmonary disease: the TORCH experience. Am J Respir Crit Care Med 2011;183:317-22.

9. Hatice K, Kokturk N, Sari G, Cakir M. Do females behave differently in COPD exacerbation? Int J Chron Obstruct Pulmon Dis 2015;10:823-30.

10. Laviolette L, Lacasse Y, Doucet M, et al. Chronic obstructive pulmonary disease in women. Can Respir J 2007;14:93-8. 11. Bakke PS, Hanoa R, Gulsvik A. Educational level and obstructive lung disease given smoking habits and occupational airborne exposure: a Norwegian community study. Am J Epidemiol 1995;141:1080-8.

12. Prescott E, Godtfredsen N, Vestbo J, Osler M. Social position and mortality from respiratory diseases in males and females. Eur Respir J 2003;21:821-6.

13. Yin P, Zhang M, Li Y, et al. Prevalence of COPD and its association with socioeconomic status in China: Findings from China Chronic Disease Risk Factor Surveillance. BMC Public Health 2011;11:586.

14. Ellison-Loschmann L, Sunyer J, Plana E, et al. Socioeconomic status, asthma and chronic bronchitis in a large communitybased study. Eur Respir J 2007;29:897-905.

15. Gershon AS, Dolmage TE, Stephenson A, Jackson B. Chronic obstructive pulmonary disease and socioeconomic status: a systematic review. COPD 2012;9:216-26.

16. Omachi TA, Sarkar U, Yelin EH, et al. Lower health literacy is associated with poorer health status and outcomes in chronic obstructive pulmonary disease. J Gen Intern Med 2012;28:74-81.

17. Lange P, Marott JL, Vestbo J, et al. Socioeconomic status and prognosis of COPD in Denmark. COPD 2014;11:431-7.

18. Noda T, Ojima T, Hayasaka S, et al. The health impact of remarriage behavior on chronic obstructive pulmonary disease: findings from the US longitudinal survey. BMC Public Health 2009;9:412.

19. Stringhini S, Carmela C, Jokela M, et al. Socioeconomic status and the $25 \times 25$ risk factors as determinants of premature mortality: a multicohort study and meta-analysis of 1.7 million men and women. Lancet 2017;389:1229-37. 
20. Odencrants S, Bjustrom T, Wiklund N, Blomberg K. Nutritional status, gender and marital status in patients with chronic obstructive pulmonary disease. J Clin Nurs 2013;22:2822-9.

21. Lee SJ, Kim SW, Kong KA, et al. Risk factors for chronic obstructive pulmonary disease among never-smokers in Korea. Int J Chron Obstruct Pulmon Dis 2015;10:497-506.

22. Pinto RA, Holanda MA, Medeiros MMC, et al. Assessment of the burden of caregiving for patients with chronic obstructive pulmonary disease. Resp Med 2007;101:2402-8.

23. Miravitlles M, María L, Longobardo P, et al. Caregivers' bur- den in patients with COPD. Int J Chron Obstruct Pulmon Dis 2015;10:347-56.

24. Agenzia per la Coesione Territoriale. Puglia - Comuni aree interne. Accessed on: 29th October 2018. Available from: http:/www.agenziacoesione.gov.it/it/arint/Selezione_aree_pro getto/Istruttoria_e_documentazione_per_regione/Regione_Pu glia/index.html

25. Donaldson GC, Goldring JJ, Wedzicha JA. Influence of season on exacerbation characteristics in patients with COPD. Chest 2012;141:94-100. 